\title{
The Status of Nursing Leadership Studies: Its Invisible Network of Knowledge
}

\author{
Yuan-Duen Lee, Shih-Hao Chen, Jen-Hwa Kuo, and Hui-Lin Chou
}

\begin{abstract}
To explore the intellectual structure of nursing leadership research in the last decade, the most crucial publications, most influential scholars, as well as the correlations among the publications of these scholars were identified. In this study, bibliometric techniques (citation analysis and cocitation analysis) were used to investigate the intellectual pillars of nursing leadership literature. By analyzing 92394 citations of 1317 articles regarding nursing leadership published from 2003 to 2012 obtained from the Science Citation Index and Social Sciences Citation Index databases, a knowledge network of nursing leadership studies was mapped. The mapping results can be used to help identify the direction of nursing leadership research and provide a valuable tool for researchers to access the literature in this field.
\end{abstract}

Index Terms-Bibliometric technique, factor analysis, nursing leadership, timeline.

\section{INTRODUCTION}

In this paper, the problems arising from the struggle to establish nursing leadership were empirically investigated by examining the literature by using citation and cocitation data obtained from Technovation. A brief review of similar bibliometric studies is presented to introduce the approach, accompanied by a description of the data. The principal investigation was a factor analysis that was performed to determine the latent structure underlying the nursing leadership literature.

Citation and cocitation are essential research tools for evaluating the core knowledge of an academic field [1], [2]. A few studies using bibliometrics to examine leadership research have been published [3], [4], but almost none have reported cocitation analysis in the nursing leadership field. Therefore, conducting this study fills the gap in nursing leadership research by providing a detailed evaluation of applying citation and cocitation to nursing leadership research.

The aim of this study was to provide leadership researchers with a unique map to improve their understanding of leadership-related publications and to provide a systematic and objective map of various themes and concepts in the development of the leadership field. The linkages among publications were also identified and their statuses, positions, and contributions to the development of the nursing

Manuscript received December 10, 2013; revised February 12, 2014.

Yuan-Duen Lee, Shih-Hao Chen, and Jen-Hwa Kuo are with the Graduate School of Business and Operations Management of the Chang Jung Christian University in Taiwan (e-mail: ydlee@mail.cjcu.edu.tw, ericchen101016@yahoo.com.tw, dynaopto@gmail.com ).

Hui-Lin Chou is with Department at Yang Ming Hospital (e-mail: hhuillin@gmail.com). leadership field were verified. Citation and cocitation analysis were the principal methods used, and a factor analysis was performed to identify the invisible network of knowledge generation underlying the nursing leadership literature. To explore the main changes in nursing leadership research in the last decade, the data was divided into two stages: the first 5 years and the second 5 years. A factor analysis was then conducted to map the intellectual structure of nursing leadership studies in these two periods. The changes in the key research topics and their implications for the evolution of nursing leadership research during the past decade are also discussed.

\section{Studies of ACADEMiC Literature: CitATiOn AND COCITATION ANALYSIS}

Various techniques can be used to examine a body of literature. The most frequently used method is the simple literature review whereby a highly subjective approach is used to structure earlier studies [5]. Objective and quantitative techniques have recently become popular as the online databases available are increasing. Bibliometrics, the application of mathematical and statistical techniques to the study of publications and professional communications, is an essential approach in multiple fields [6]. Two of the most indispensable and widely used tools are citation and cocitation analysis. Citation analysis is based on the assumption that authors cite papers they consider crucial for the development of their research, and that heavily cited articles are more likely to have exerted a substantial influence on the subject than those that are less frequently cited [7]. This tool was popularized by the work of Garfield [8], who applied citation analysis to preexisting indexes, the Science Citation Index (SCI) and Social Sciences Citation Index (SSCI).

\section{A. Citation Analysis}

The citation analysis method is mainly used to analyze the reference phenomenon or objects of journals, papers, and authors, and to explore the relationship between the sources of literature and citations. Implementing this method can help researchers understand the current state of development of certain disciplines, the literature usage characteristics in these disciplines, the correlations among disciplines in the literature, and future trends of research.

\section{B. Cocitation}

Cocitation is the frequency at which two documents or authors are cited together by recent papers [9]. A cocitation analysis of documents is conducted by recording the number of papers that have cited any particular pair of documents and 
it is interpreted as a measure of the similarity of the content of the two documents. The approach is instrumental in identifying groupings of authors, topics, or methods, and can help clarify how these clusters interrelate [10]. Specifically, in cocitation studies, cocitation counts are compiled in matrix form and statistically scaled to record, at a distinct point in time, what is actually a changing and evolving structure of knowledge [11]. Therefore, cocitation analysis was considered an efficient method for measuring relationships and linkages between authors, papers, and journals to describe the mainstream or cutting-edge research in science [12].

\section{Methodology}

In this study, the SCI and SSCI were used for analysis. SCI and SSCI are widely used databases that include articles published in more than 8000 of the leading scholarly journals worldwide. Arguments that other online databases might also be used for such analysis exist; however, using SCI and SSCI provided the most comprehensive and most acceptable databases of nursing leadership publications. To collect the data, a keyword was used to identify the relevant article titles and abstracts in the SCI and SSCI. Using "nursing leadership" as the keyword, 1317 journal articles were collected, and those articles cited 92394 publications as references.

\begin{tabular}{|c|c|c|c|}
\hline Journal & $\begin{array}{l}\text { Total } \\
\text { Citation } \\
\end{array}$ & Journal & $\begin{array}{l}\text { Total } \\
\text { Citation }\end{array}$ \\
\hline Journal of Nursing & 1794 & Nursing Administration & 313 \\
\hline Administration & & Quarterly & \\
\hline $\begin{array}{l}\text { Journal of Advanced } \\
\text { Nursing }\end{array}$ & 1735 & Medical Care & 304 \\
\hline $\begin{array}{l}\text { Journal of Nursing } \\
\text { Management }\end{array}$ & 1290 & $\begin{array}{l}\text { Nurse Education } \\
\text { Today }\end{array}$ & 279 \\
\hline $\begin{array}{l}\text { Journal of Clinical } \\
\text { Nursing }\end{array}$ & 601 & $\begin{array}{l}\text { Journal of Nursing } \\
\text { Education }\end{array}$ & 275 \\
\hline $\begin{array}{l}\text { JAMA-Journal of the } \\
\text { American Medical } \\
\text { Association }\end{array}$ & 540 & $\begin{array}{l}\text { Journal of The } \\
\text { American Geriatrics } \\
\text { Society }\end{array}$ & 272 \\
\hline $\begin{array}{l}\text { British Medical } \\
\text { Journal }\end{array}$ & 450 & Nursing Outlook & 267 \\
\hline Nursing Research & 433 & $\begin{array}{l}\text { Quality \& Safety in } \\
\text { Health Care }\end{array}$ & 216 \\
\hline $\begin{array}{l}\text { Journal of Applied } \\
\text { Psychology }\end{array}$ & 407 & Critical Care Medicine & 187 \\
\hline $\begin{array}{l}\text { International Journal of } \\
\text { Nursing Studies }\end{array}$ & 369 & $\begin{array}{l}\text { Journal of Professional } \\
\text { Nursing }\end{array}$ & 92 \\
\hline Nursing Economics & 351 & $\begin{array}{l}\text { Research in Nursing \& } \\
\text { Health }\end{array}$ & 67 \\
\hline Gerontologist & 333 & $\begin{array}{l}\text { Journal of Nursing Care } \\
\text { Quality }\end{array}$ & 56 \\
\hline $\begin{array}{l}\text { New England Journal } \\
\text { of Medicine }\end{array}$ & 321 & Leadership Quarterly & 56 \\
\hline
\end{tabular}

The citation data used in this study included journal articles, authors, publication journals, publication dates, and cited references. Based on the objective of this study, the intellectual structure of nursing leadership between 2003 and 2012 was explored. This period was chosen because contemporary nursing leadership studies conducted during the last decade represent the most up-to-date and likely the most crucial research. Citation and cocitation analysis were the main methods used in this study. By using citation and cocitation analysis, three stages were assumed in this research, each of which required different approaches for examining the development of nursing leadership studies. First, the databases were identified as the sources of nursing leadership publications. Data collection and analysis techniques were then designed to collect information regarding research topics, authors, and journals on nursing leadership research.

Bibliometrics were employed to accomplish the following goals: 1) map the cocitation networks of the leadership studies from the past 10 years; and 2) examine the links between the primary scholars who authored key articles on nursing leadership research. The general procedure for cocitation analysis involves the following steps: 1) compilation of a raw cocitation matrix; 2) conversion of the data matrix to a correlation matrix; 3) analysis of the correlation matrix through factor analysis; and 4) interpretation and validation of the results [13]. The analyses were conducted using Ucinet 6.0 for Windows [14].

\section{Results}

\section{A. Citation Analysis}

To identify the key publications and scholars that have established the foundation of nursing leadership research, citation data were tabulated for each of the 1317 source documents and 92394 references by using Microsoft Excel. The citation analysis produced remarkable background statistics, as shown in the following tables. Table I lists the most cited journals in the digital divide area during the previous decade, among which the Journal of Nursing Administration, Journal of Advanced Nursing, and Journal of Nursing Management were the three most cited journals. The general pattern of the most cited journals showed that nursing leadership research features journals that specifically discuss management, education, and nursing care.

\begin{tabular}{ll}
\multicolumn{2}{c}{ TABLE II: HIGHLY CITED DOCUMENTS: 2003-2007 } \\
\hline \multicolumn{1}{c}{ Full Citation Index For Document } & $\begin{array}{l}\text { Total } \\
\text { Citations }\end{array}$ \\
\hline Aiken LH, 2002, JAMA-J AM MED ASSOC, V288, P1987 & 19 \\
Needleman J, 2002, NEW ENGL J MED, V346, P1715 & 14 \\
Aiken LH, 2001, HEALTH AFFAIR, V20, P43 & 13 \\
Institute of Medicine, 2004, KEEP PAT SAF TRANSF & 13 \\
Burns J. M., 1978, LEADERSHIP & 12 \\
Institute of Medicine, 2001, CROSS QUAL CHASM NEW & 12 \\
Rogers EM, 1995, DIFFUSION INNOVATION & 12 \\
Bass B. M., 1985, LEADERSHIP PERFORMAN & 11 \\
McCormack B, 2002, J ADV NURS, V38, P94 & 11 \\
Porter-O'Grady T, 2003, J NURS ADMIN, V33, P173 & 11 \\
Rycroft-Malone J, 2002, QUAL SAF HEALTH CARE, V11, & 11 \\
P174 & 10 \\
Kitson A, 1998, QUAL HEALTH CARE, V7, P149 & 10 \\
SHORTELL SM, 1991, MED CARE, V29, P709 & 10 \\
SHORTELL SM, 1994, MED CARE, V32, P508 & \\
\hline
\end{tabular}

The most cited and most influential documents by the most influential scholars were then identified using their total counts of citations within the selected journal articles. As shown in Table II, the most cited nursing leadership publication between 2003 and 2007 (the first 5 years) was "Hospital Nurse Staffing and Patient Mortality, Nurse Burnout, and Job Dissatisfaction" by Aiken, followed by "Nurse-staffing Levels and the Quality of Care in Hospitals" 
by Needleman, and 'Nurses' Reports on Hospital Care in Five Countries" by Aiken (Table II).

For the second 5 years (2008-2012), the most cited nursing leadership publication was "Hospital Nurse Staffing and Patient Mortality, Nurse Burnout, and Job Dissatisfaction" by Aiken, which is the same as in the first 5 years. The other two most cited publications were "Crossing the Quality Chasm: A New Health System for the 21st Century" by the Institute of Medicine and "The Relationship Between Nursing Leadership and Patient Outcomes: A Systematic Review" by Wong (Table III).

TABLE III: HiGHLY CITED DOCUMENTS: 2008-2012

\begin{tabular}{ll}
\hline \multicolumn{1}{c}{ Full Citation Index For Document } & $\begin{array}{l}\text { Total } \\
\text { Citations }\end{array}$ \\
\hline Aiken LH, 2002, JAMA-J AM MED ASSOC, V288, P1987 & 46 \\
Wong Carol A, 2007, J Nurs Manag, V15, P508 & 39 \\
Institute of Medicine, 2001, CROSS QUAL CHASM NEW & 33 \\
Bass B. M., 1985, LEADERSHIP PERFORMAN & 29 \\
Graneheim UH, 2004, NURS EDUC TODAY, V24, P105 & 29 \\
Aiken LH, 2001, HEALTH AFFAIR, V20, P43 & 27 \\
Aiken LH, 2000, NURS RES, V49, P146 & 26 \\
McCormack B, 2002, J ADV NURS, V38, P94 & 24 \\
Burns J. M., 1978, LEADERSHIP & 23 \\
Lincoln Y. S., 1985, NATURALISTIC INQUIRY & 23 \\
Institute of Medicine, 2004, KEEP PAT SAF TRANSF & 22 \\
Miles M.B, 1994, QUALITATIVE DATA ANA & 22 \\
Aiken LH, 2002, JAMA-J AM MED ASSOC, V288, P1987 & 46 \\
Wong Carol A, 2007, J Nurs Manag, V15, P508 & 39 \\
\hline
\end{tabular}

When the journal articles and books were combined, the six most cited scholars between 2003 and 2007 (the first 5 years) were Aiken, Laschinger, Bass, Rycroft-Malone, Estabrooks, and Shortell (Table IV). For the second 5 years, the six most cited scholars were Aiken, Laschinger, Bass, Castle, Kramer, and Estabrooks (Table V). These scholars exerted the greatest influence on the development of the digital divide area and thus collectively define this field. Their contributions represent the focus of the main research in the field and thus provide an indication of the popularity of certain nursing leadership topics as well as their historical value.

TABLE IV: HighLy CITED AUTHORS: 2003-2007

\begin{tabular}{llll}
\hline Author & Frequency & Author & Frequency \\
\hline Aiken LH & 85 & Anderson RA & 28 \\
Laschinger HKS & 44 & Porter-O'Grady T & 26 \\
Bass B. M. & 34 & KRAMER M & 22 \\
Rycroft-Malone J & 32 & Grol R & 21 \\
Estabrooks CA & 31 & Stetler CB & 21 \\
Shortell SM & 29 & Rogers EM & 20 \\
\hline
\end{tabular}

TABLE V: Highly CiTED AUTHORS: 2008-2012

\begin{tabular}{llll}
\hline Author & Frequency & Author & Frequency \\
\hline Aiken LH & 203 & Rycroft-Malone J & 55 \\
Laschinger & 198 & Duffield C & 52 \\
HKS & 83 & Parse RR & 51 \\
Bass B. M. & 74 & McCormack B & 49 \\
Castle NG & 58 & Shirey MR & 49 \\
Kramer M & 55 & Tourangeau AE & 49 \\
Estabrooks CA & 55 & & \\
\hline
\end{tabular}

\section{B. Cocitation Analysis}

In this stage, data mapping was conducted and the intellectual structure of the current nursing leadership studies was revealed. Cocitation analysis is a bibliometric technique that information scientists use to map the intellectual structure of an academic field. It involves counting documents from a chosen field, either paired or cocited documents. To conduct cocitation analysis, cocitation counts in matrix form are compiled and statistically scaled to record, at a distinct point in time, what is actually a changing and evolving structure of knowledge [15]. Cocitations were tabulated for each source document by using Microsoft Excel. Most of the authors had extremely limited cocitations that were either unlikely to have exerted a considerable influence on the development of the field or were too new to have had time to affect the literature. To facilitate analyses and improve the probability of its success, it was ensured that all authors in the final set had at least 30 citations in the first 5 years and 30 in the second 5 years. The cocitation correlation matrix was factor analyzed using varimax rotation, a commonly used procedure that attempts to fit (or load) the maximum number of authors in the minimum number of factors. The diagonals were considered missing data and the criterion for omitting the two cases were applied [16].

Three factors were extracted from the data in the first 5 years (2003-2007) and together, $65.8 \%$ of the variance in the correlation matrix was attributable to these factors. Table 6 lists the three most crucial factors and the authors that had a factor loading of at least 0.5 . As is standard in this type of analysis, authors with less than a 0.5 loading or with cross-loadings were eliminated from the final results [17]. Names were tentatively assigned to the factors based on how the authors with high loadings were interpreted. The interpretation of the analysis results was that nursing leadership research in this period comprised at least three different subfields: job satisfaction, evidence into practice, and communication (Table VI). Because the remaining factors had small eigenvalues, they were not interpreted. They were also excluded from Table VI.

TABLE VI: AUTHOR FACTOR LOADINGS: 2003-2007

\begin{tabular}{|c|c|c|c|}
\hline $\begin{array}{l}\text { Factor1: } \\
\text { Nurses' job satisfaction }\end{array}$ & variance & $\begin{array}{l}\text { Factor2: } \\
\text { Evidence into practice }\end{array}$ & variance \\
\hline Blegen MA & 0.833 & Estabrooks CA & 0.87 \\
\hline Needleman J & 0.806 & Wallin L & 0.826 \\
\hline Buerhaus PI & 0.765 & Stetler CB & 0.821 \\
\hline Maslach C & 0.734 & Rycroft-Malone J & 0.781 \\
\hline Porter-O'Grady T & 0.734 & Harvey $\mathrm{G}$ & 0.727 \\
\hline Laschinger HKS & 0.716 & Mccormack B & 0.712 \\
\hline Baggs JG & 0.705 & Kitson A & 0.692 \\
\hline Shortell SM & 0.664 & Benner P. & 0.618 \\
\hline Kramer M & 0.539 & Grol R & 0.514 \\
\hline $\begin{array}{l}\text { Factor3: } \\
\text { Communication }\end{array}$ & variance & & \\
\hline Rogers EM & 0.612 & & \\
\hline Anderson RA & 0.578 & & \\
\hline Grol R & 0.574 & & \\
\hline Schnelle JF & 0.571 & & \\
\hline Department of Health & 0.555 & & \\
\hline
\end{tabular}

The first factor that appears in Table VI is job satisfaction, as defined by Blegen. In a previous metaanalysis, Blegen [18] observed that job satisfaction was most strongly correlated with job stress and moderately correlated with communication with supervisors, autonomy, and communication with peers. In addition to job satisfaction, autonomy, job stress, and nurse-physician collaboration were major concepts in the metaanalysis [18]. Another study revealed that multiple RNs asserted that they were working harder than ever, that work satisfaction and morale were suffering, and that the quality of patient care has deteriorated over the past few years [19]. 
The second factor was defined by Stetler, Ritchie, Rycroft-Malone, Schultz, and Charn. Organizational context is receiving attention from researchers across multiple disciplines as a potential factor in the successful implementation of evidence into practice. Evidence-based practice (EBP) is an approach expected to improve the quality of patient care and service delivery in health care systems. Based on Stetler, Ritchie, Rycroft-Malone, Schultz, and Charn's finding [20], the most influential EBP leaders were of long-standing tenure at the time of the site visit and have been present from the start or before the initiative, have been visibly progressing, and possess a continuing and deep commitment to EBP. The results of the study by Stetler et al. [20] were also consistent with qualitative findings that indicated that the role model site's leadership, culture, and related staff attitudes were more developed regarding the support of EBP [20].

The third factor representing the communication of nursing leadership was defined by Everett and Kincaid [21]. Everett and Kincaid [21] argued that communication research has been hampered in the past by a research paradigm that, like that of most surveys, uses only the individual as the unit of analysis. The result was theory unable to effectively process human communication as a "process of mutual information exchange." To obtain a thorough understanding of human behavior, Everett and Kincaid [21] sought to upgrade communication theory by incorporating social network concepts into the related methodology.

Similarly, studies on nursing leadership have also focused on different research themes between 2008 and 2012, and more than $68 \%$ of the variance in the correlation matrix of the second 5 years were attributable to these studies, as demonstrated in Table VII, which lists the eight most crucial factors along with the authors that had a factor loading of at least 0.5 . Names were also tentatively assigned to the factors based on how the authors with high loadings were interpreted. The interpretation of the analysis results was that nursing leadership research in this period also comprised at least three different subfields:

The first factor that appears in Table VII is nursing leadership as defined by Shirey and Fisher. Just as Shirey and Fisher mentioned [22], nurses identified leaders' empowering behaviors (inclusive of support) as crucial requirements of the desirable practice environment necessary for nurse retention. Without support for external development and networking, organizations might not be able to systematically guarantee a common staff awareness of industry trends and issues that promote optimal patient care. Leaders play a pivotal role in nurse retention by shaping the health care practice environment to produce quality outcomes for nurses and patients [22].

The second factor was evidence into practice of nursing leadership. According to McCormack [23], leaders must combine the "science" component of health care practice (the application of science and technology) and the "art" component (the translation of different forms of practice knowledge) into caring actions. Making such values explicit enables the creation of a measurement framework that reflects both existing and intended practice cultures.

The third factor was defined by Akerjordet and
Severinsson, and identifies the value of emotional intelligence in nursing leadership. Akerjordet and Severinsson [24] mentioned that emotional intelligence in leadership skills is vital for creating a supportive environment and facilitating positive empowerment processes that lead to subjective well-being. The emotional intelligence of a leader is critical in effective nurse leadership because it enables the means to build on existing strengths for the common good. In addition, nurse leaders with emotional intelligence behave authentically and supportively, fostering a healthy environment and creating a work climate characterized by wisdom, innovation, and change.

TABLE VII: AUTHOR FACTOR LOADINGS: 2008-2012

\begin{tabular}{lcll}
\hline $\begin{array}{l}\text { Factorl: } \\
\text { Work Environment }\end{array}$ & variance & $\begin{array}{l}\text { Factor2: } \\
\text { Evidence into Practice }\end{array}$ & variance \\
\hline Cummings G & 0.678 & Benner P. & 0.748 \\
Duffield C & 0.857 & Estabrooks CA & 0.672 \\
Estabrooks CA & 0.593 & Kitson A & 0.763 \\
Lake ET & 0.94 & McCormack B & 0.727 \\
Laschinger HKS & 0.787 & Rycroft-Malone J & 0.819 \\
Manojlovich M & 0.881 & & \\
Pronovost PJ & 0.742 & & \\
Shirey MR & 0.825 & & \\
SHORTELL SM & 0.505 & & \\
Tourangeau AE & 0.916 & & \\
Castle NG & 0.407 & & \\
\hline Factor3: & variance & & \\
Emotional & & & \\
Intelligence & & & \\
\hline Akerjordet K & 0.855 & & \\
Wong Carol A & 0.667 & & \\
Shirey MR & 0.4 & & \\
\hline
\end{tabular}

TABLE VIII: HISTORICAL TIMELINE OF NURSING LEADERSHIP: 2003-2007

\begin{tabular}{|c|c|c|c|}
\hline Timeline & Citations & Type & Title \\
\hline 1978 & 12 & $\mathrm{~B}$ & Burns J. M., LEADERSHIP \\
\hline 1984 & 8 & B & Benner P., NOVICE EXPERT EXCELL \\
\hline 1985 & 11 & B & $\begin{array}{c}\text { Bass B. M., LEADERSHIP } \\
\text { PERFORMAN }\end{array}$ \\
\hline 1991 & 10 & $\mathrm{~J}$ & $\begin{array}{c}\text { SHORTELL SM, MED CARE, V29, } \\
\text { P709 }\end{array}$ \\
\hline 1994 & 10 & $\mathrm{~J}$ & $\begin{array}{l}\text { SHORTELL SM, MED CARE, V32, } \\
\text { P508 }\end{array}$ \\
\hline 1994 & 9 & $\mathrm{~J}$ & AIKEN LH, MED CARE, V32, P771 \\
\hline 1995 & 12 & B & $\begin{array}{c}\text { Rogers EM, DIFFUSION } \\
\text { INNOVATION }\end{array}$ \\
\hline 1995 & 8 & $\mathrm{~J}$ & $\begin{array}{l}\text { MCNEESESMITH D, J NURS ADMIN, } \\
\text { V25, P17 }\end{array}$ \\
\hline 1997 & 9 & $\mathrm{~J}$ & $\begin{array}{l}\text { Morrison RS, J NURS ADMIN, V27, } \\
\text { P27 }\end{array}$ \\
\hline 1998 & 10 & $\mathrm{~J}$ & $\begin{array}{c}\text { Kitson A, QUAL HEALTH CARE, V7, } \\
\text { P149 }\end{array}$ \\
\hline 1999 & 7 & $\mathrm{~J}$ & Antrobus S, J ADV NURS, V29, P746 \\
\hline 2000 & 7 & $\mathrm{~J}$ & Aiken LH, NURS RES, V49, P146 \\
\hline 2001 & 13 & $\mathrm{~J}$ & Aiken LH, HEALTH AFFAIR, V20, P43 \\
\hline 2002 & 19 & $\mathrm{~J}$ & $\begin{array}{c}\text { Aiken LH, JAMA-J AM MED ASSOC, } \\
\text { V288, P1987 }\end{array}$ \\
\hline 2002 & 14 & $\mathrm{~J}$ & $\begin{array}{c}\text { Needleman J, NEW ENGL J MED, } \\
\text { V346, P1715 }\end{array}$ \\
\hline 2002 & 11 & $\mathrm{~J}$ & $\begin{array}{c}\text { Rycroft-Malone J, QUAL SAF HEALTH } \\
\text { CARE, V11, P174 }\end{array}$ \\
\hline 2003 & 11 & $\mathrm{~J}$ & $\begin{array}{c}\text { Porter-O'Grady T, J NURS ADMIN, } \\
\text { V33, P173 }\end{array}$ \\
\hline 2003 & 9 & $\mathrm{~J}$ & $\begin{array}{c}\text { Porter-O'Grady T, J NURS ADMIN, } \\
\text { V33, P105 }\end{array}$ \\
\hline
\end{tabular}

\section{Research Timeline}

The objective of this paper was to trace the evolution of the intellectual structure of the nursing leadership field. The historical timeline of research concepts, themes, and methods in $2 \mathrm{D}$ scale provides a clear overview of the nursing leadership research path in the period from 2003 to 2012 (Figs. 1 and 2). Dramatic changes are affecting the world of 
work; therefore, the main topics in nursing leadership studies are also changing. Common topics include increased human factor, the impact of nursing leadership, the shift from vertically integrated hierarchies to networks of specialists, hospital managers, and the change in the paradigm of performing safe operations from performing surgery to providing a service. In addition, the definition of work itself is evolving; the idea of a job as a fixed collection of tasks is disappearing, and there is a new emphasis on constantly evolving practices to fulfill the ever-increasing demands of patients. Hospital managers have a great opportunity to contribute to the betterment of human welfare in the context of these changes. However, leading this change rather than simply following it requires a break from traditional practices and a focus on rigorous research that addresses emerging trends. Several new and old topics and keywords demonstrate the view of nursing leaders as a dynamic entity in constant interaction with their environments, as shown in Tables 8 and 9 and Figs. 1 and 2. In other words, hospitals must adapt to the substantial changes that are occurring regarding precludes, management, and service values.

TABLE IX: HISTORICAL TIMELINE OF NURSING LEADERSHIP: 2008-2012

\begin{tabular}{|c|c|l|l|}
\hline Timeline & Citations & Type & \multicolumn{1}{|c|}{ Title } \\
\hline 1978 & 23 & J & Burns J. M., LEADERSHIP \\
\hline 1984 & 21 & J & $\begin{array}{l}\text { Benner P., NOVICE EXPERT } \\
\text { EXCELL }\end{array}$ \\
\hline
\end{tabular}

\begin{tabular}{|l|l|l|l|}
\hline 1985 & 29 & B & $\begin{array}{l}\text { Bass B. M., LEADERSHIP } \\
\text { PERFORMAN }\end{array}$ \\
\hline 1985 & 23 & J & $\begin{array}{l}\text { Lincoln Y. S., NATURALISTIC } \\
\text { INQUIRY }\end{array}$ \\
\hline 1994 & 22 & J & $\begin{array}{l}\text { Miles M.B, QUALITATIVE } \\
\text { DATA ANA }\end{array}$ \\
\hline 1998 & 19 & J & $\begin{array}{l}\text { Kitson A, QUAL HEALTH } \\
\text { CARE, V7, P149 }\end{array}$ \\
\hline 1999 & 20 & J & $\begin{array}{l}\text { Laschinger HKS, J NURS } \\
\text { ADMIN, V29, P28, }\end{array}$ \\
\hline 2000 & 26 & J & $\begin{array}{l}\text { Aiken LH, NURS RES, V49, } \\
\text { P146 }\end{array}$ \\
\hline 2001 & 27 & J & $\begin{array}{l}\text { Aiken LH, HEALTH AFFAIR, } \\
\text { V20, P43 }\end{array}$ \\
\hline 2002 & 46 & J & $\begin{array}{l}\text { Aiken LH, JAMA-J AM MED } \\
\text { ASSOC, V288, P1987 }\end{array}$ \\
\hline 2002 & 24 & B & $\begin{array}{l}\text { McCormack B, J ADV NURS, } \\
\text { V38, P94 }\end{array}$ \\
\hline 2002 & 20 & J & $\begin{array}{l}\text { Lake ET, RES NURS HEALTH, } \\
\text { V25, P176 }\end{array}$ \\
\hline 2003 & 20 & J & $\begin{array}{l}\text { Anderson RA, NURS RES, V52, } \\
\text { P12 }\end{array}$ \\
\hline 2004 & 29 & J & $\begin{array}{l}\text { Graneheim UH, NURS EDUC } \\
\text { TODAY, V24, P105 }\end{array}$ \\
\hline 2006 & 20 & J & $\begin{array}{l}\text { Sellgren Stina, J Nurs Manag, } \\
\text { V14, P348, }\end{array}$ \\
\hline 2007 & 39 & J & $\begin{array}{l}\text { Wong Carol A, J Nurs Manag, } \\
\text { V15, P508 }\end{array}$ \\
\hline 2008 & 19 & J & $\begin{array}{l}\text { Aiken LH, J NURS ADMIN, V38, } \\
\text { P223 }\end{array}$ \\
\hline 2010 & 19 & J & $\begin{array}{l}\text { Cummings GG, INT J NURS } \\
\text { STUD, V47, P363 }\end{array}$ \\
\hline
\end{tabular}

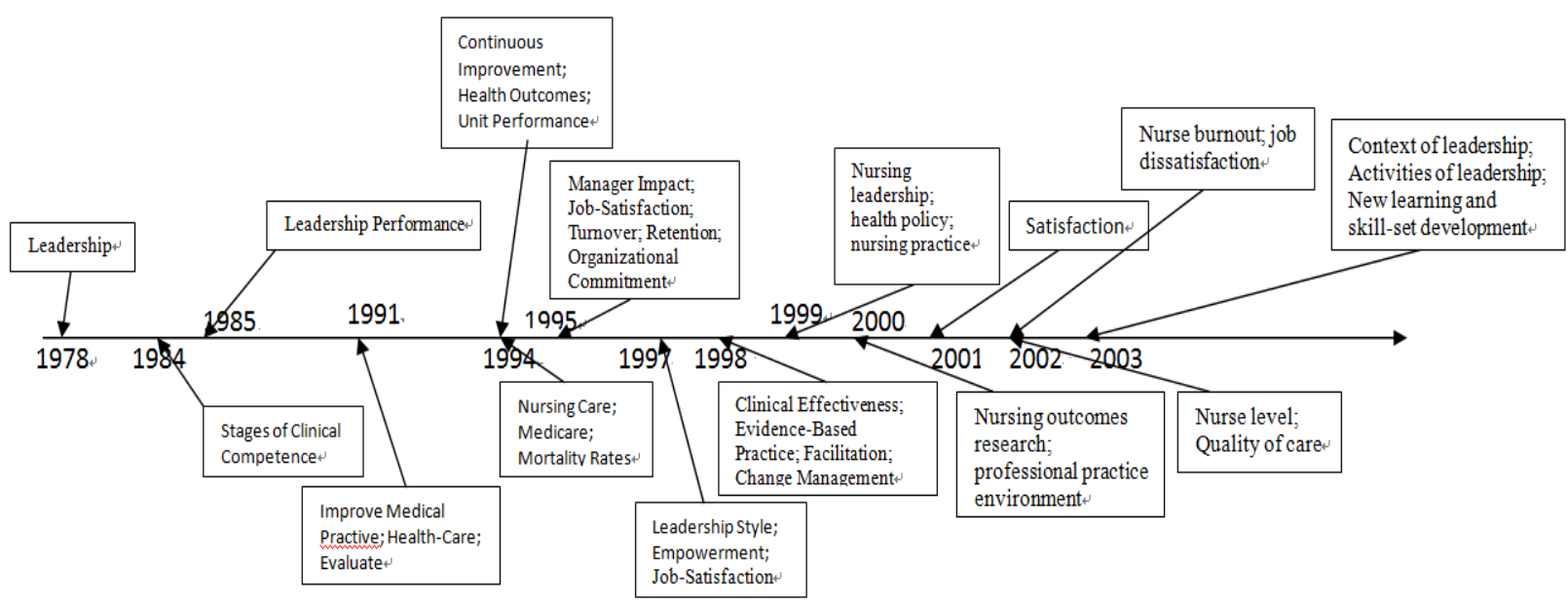

Fig. 1. Research topics and keywords historical timeline of nursing leadership: 2003-2007.

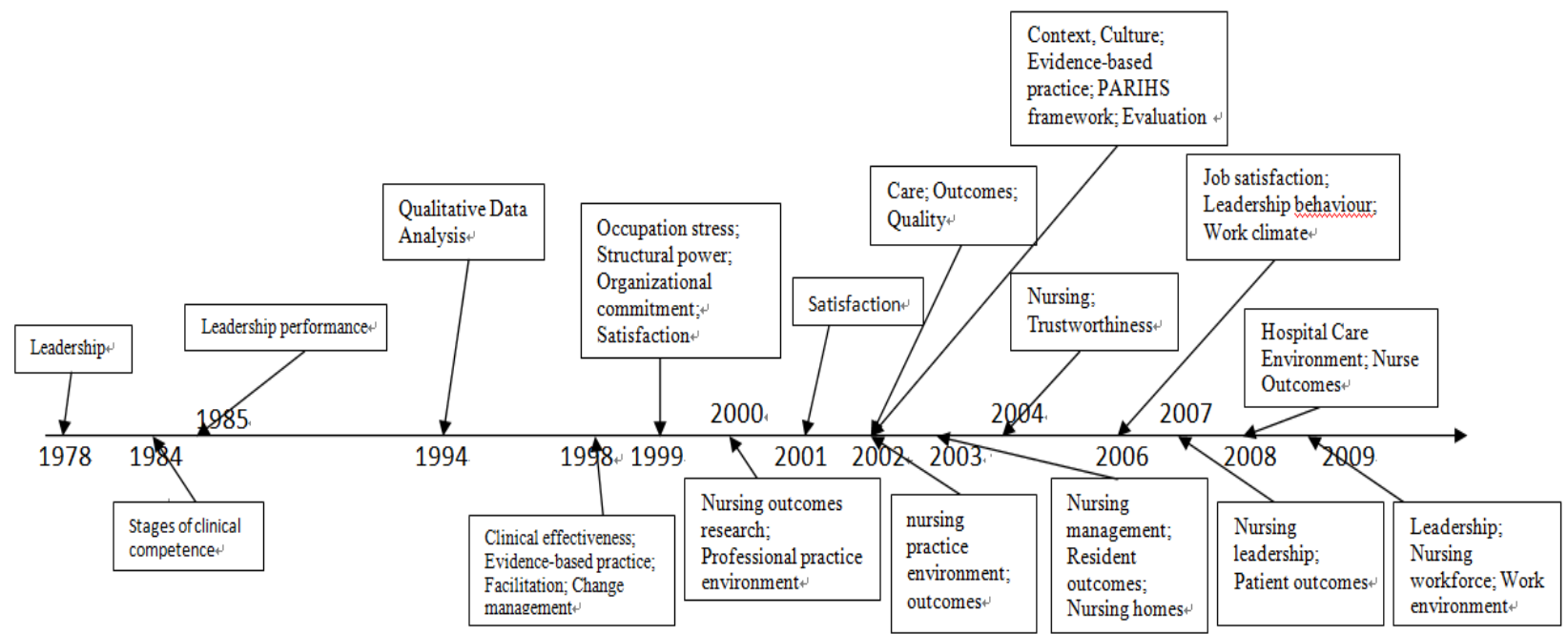

Fig. 2. Research topics and keywords historical timeline of nursing leadership: 2008-3012. 


\section{CONCLUSION}

Nursing leadership was extensively studied during the past decade. In this study, nursing leadership research was investigated using citation and cocitation data published in the SCI and SSCI between 2003 and 2012. Using a factor analysis of the cocitation data, the intellectual structure of nursing leadership research was mapped, and the results suggest that contemporary nursing leadership research is organized according to different concentrations of interest: work environment, evidence into practice, communication, emotional intelligence, and job satisfaction.

The mapping of the intellectual structure of nursing leadership studies indicated that the field now has its own literature and that it has developed into a legitimate academic field. The publication of nursing leadership-specific journals, such as the Journal of Nursing Administration, Journal of Advanced Nursing, and Journal of Nursing Management, indicates that nursing leadership has gained the status required for an independent research field. Because the nursing leadership field is still new and the analysis has shown that it has an evolving structure, it is believed that nursing leadership publication outlets will gain the popularity and prestige that is required to become a more prominent academic field when the current paradigms and key research themes in nursing leadership studies, how they interrelate, and what they represent have been identified. As the number of scholars and resources contributing to nursing leadership increases, the academic environment conducive for the cross-fertilization of research ideas will be formed and nursing leadership as a research field will gain more momentum for further development.

\section{REFERENCES}

[1] H. Small, "Co-citation in the scientific literature: A new measure of the relationship between two documents," Journal of the American Society for Information Science, vol. 24, no. 4, pp. 265-269, 1973.

[2] I. V. Marshakova, "A system of document connections based on references," Scientific and Technical Information Serial of VINITI, vol. 6, no. 2, pp. 3-8, 1973.

[3] Y. D. Lee, Y. McLee, and C. F. Huang, "The status of leadership studies: its invisible network of knowledge," International Journal of Management and Technology, vol. 1, no. 1, pp. 167-182, 2011.

[4] C. T. Kuo and Y. McLee, "Evolution of the intellectual structure of leadership studies in the last decade: perspective on the invisible network of knowledge," The Journal of Human Resource and Adult Learning, vol. 8, no. 2, pp. 182-192, 2012.

[5] A. Drejer, "The discipline of management of technology, based on considerations related to technology," Technovation, vol. 17, no. 5, pp 253-265, 1997.

[6] V. Diodato, Dictionary of Bibliometrics, Haworth Press, Binghamton, New York, 1994

[7] Z. Ma, Y. Lee, and K. Yu, "Ten years of conflict management studies: Themes, concepts, and relationships," International Journal of Conflict Management, vol. 19, no. 3, pp. 234-248, 2008.

[8] E. Garfield, "Citation analysis as a tool in journal evaluation," Science, vol. 178, no. 4060, pp. 471-479, 1972.

[9] J. Alger, "Can rank be used to generate a reliable author list for co-citation studies?" College and Research Libraries, vol. 57, no. 6, pp $567-574,1996$

[10] A. Pilkington and C. Liston-Heyes, "Is production and operations management a discipline? Acitation/co-citation study," International Journal of Operations and Production Management, vol. 19, pp. 7-20, 1999.

[11] H. G. Small, "Macro-level changes in the structure of co-citation clusters: 1983-1989," Scientometrics, vol. 26, pp. 5-20, 1993.
[12] M. Y. Tsay, H. Xu, and C. W. Wu, "Author co-citation analysis of semiconductor literature," Scientometrics, vol. 58, no. 3, pp. 529-545, 2003.

[13] J. Alger, "Can RANK is used to generate a reliable author list for co-citation studies?" College Research Libraries, vol. 57, no. 6, pp. 567-574, 1996.

[14] S. P. Borgatti, M. G. Everett, and L. C. Freeman, Ucinet 6 for Windows, Harvard: Analytic Technologies, 2002.

[15] H. G. Small, "Macro-level changes in the structure of co-citation clusters: 1983-1989," Scientometrics, vol. 26, pp. 5-20, 1993.

[16] K. W. McCain, "Mapping authors in intellectual space: a technical overview,', Journal of the American Society for Information Science, vol. 41, pp. 433-43, 1990.

[17] H. D. White and B. Griffith, "Author co-citation: a literature measure of intellectual structure," Journal of the American Society for Information Science, vol. 32 no. 3, pp. 163-71, 1981.

[18] M. A. Blegen, "Nurses' job satisfaction: a meta-analysis of related variables,'” Nursing Research, vol. 42, no.1, pp.36-41, 1993.

[19] P. I. Buerhaus and D. O .Staiger, "Trouble in the nurse labor market? Recent trends and future outlook," Health Affairs, vol. 18, no. 1, pp. 214-222, 1999.

[20] C. B. Stetler, J. A. Ritchie, J. R. Malone, A. A. Schultz, and M. P. Charns, "Improving quality of care through routine, successful implementation of evidence-based practice at the bedside: an organizational case study protocol using the Pettigrew and Whipp model of strategic change,', Implementation Science, vol. 2, no. 3, 2007.

[21] E. M. Rogers and D. L. Kincaid, "Communication networks: toward a new paradigm for research," American Journal of Sociology, vol. 89, no. 4, pp. 986-988, 1981

[22] M. R. Shirey and M. L. Fisher, "leadership agenda for change toward healthy work environments in acute and critical care,' Critical Carenurse, vol. 28, no. 5, pp. 66-79, 2008.

[23] B. McCormack, A. Kitson, C. Harvey, J. R. Malone, A. Titchen, and K Seers, "Getting evidence into practice: the meaning of 'context',' Journal of Advanced Nursing, vol. 38, no. 1, pp. 94-104, 2002.

[24] K. Akerjordet and E. Severinsson, "Emotionally intelligent nurse leadership: a literature review study,' Journal of Nursing Management, vol. 16, pp. 565-577, 2008.

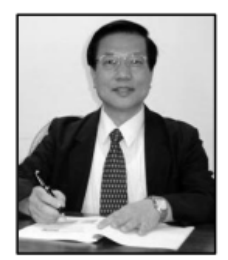

Yuen-Duan Lee is a professor at the Graduate School of Business and Operations Management of Chang Jung Christian University, Taiwan. He received his Ph.D. degree from the education management and human resources Department at Drake University, United States. His research interests include international business topics, strategic human resource management, organizational behavior, and leadership.

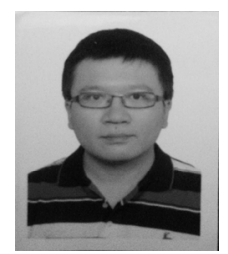

Shih-Hao Chen is a doctoral student at the Graduate School of Business and Operations Management, Chang Jung Christian University, Taiwan. He received his M.B.A. degree from the graduate School of business and operations management, Chang Jung Christian University, Taiwan. His research interests include human resource management and organizational behavior.

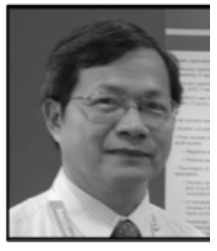

Jen-Hwa Kuo is a doctoral student at the Graduate School of Business and Operations Management, Chang Jung Christian University, Taiwan. He received his M.S. degree from the graduate institute of industrial economics at National Central University, Taiwan. His research interests include enterprise resource planning, management information systems, and accounting.

Hui-Lin Chou is the director of Nursing Department at Yang Ming Hospital. She is also a doctoral student at the Graduate School of Business and Operations Management, Chang Jung Christian University, Taiwan. She received her master's degree from the Department of public and cultural affairs at national Taitung University, Taiwan. Her research interests include human resource management, nursing management, and public policy. 